\title{
Rubus Plant Regeneration via Asexual Embryogenesis
}

\author{
V.M. Gingas ${ }^{1}$ and B.D. Stokes \\ Agriculture Department, Southern State Community College, Hillsboro, \\ $\mathrm{OH} 45133$
}

Additional index words. raspberry, tissue culture, micropropagation, somatic embryogenesis

The objective of this study was to develop an asexual embryogenic regeneration system for Rubus, even though previous attempts had proved unsuccessful (Fiola and Swartz, 1986).

In an initial experiment, fruits of fieldgrown $R$. occidentalis 'Bristol' and 'Jewel' and $R$. idaeus 'Exp-72' plants were collected at the early green, late-green or early yellow, and the red stages of ripeness. Seeds were extracted and disinfested in a $0.5 \%$ sodium hypochlorite and $0.5 \%$ Alconox solution for $15 \mathrm{~min}$ followed by two 30 -sec sterile distilled water rinses. Cotyledon explants (0.5 to 1.0 $\mathrm{mm}$ ) were excised from embryos that had been aseptically dissected from the seeds and cultured on a modified MS medium (Murashige and Skoog, 1962) containing $200 \mathrm{mg}$ casein hydrolysate/liter, $3 \%$ sucrose, and $0,0.45$, or $4.5 \mu \mathrm{M}$ (2,4-dichlorophenoxy)acetic acid (2,4D). For the three stages of ripeness, we used 133, 56, and60 explants for 'Bristol'; 143, 60, and 77 for 'Jewel'; and 64, 166, and 60 for 'Exp-72', with each group divided equally among growth regulator treatments. The $\mathrm{pH}$ of the medium was adjusted to 5.7 before adding $0.25 \%$ Gelrite (Scott Laboratories, Atlanta) and autoclaving. Cultures were incubated at 24C under cool-white fluorescent illumination $\left(70 \mu \mathrm{mol} \cdot \mathrm{m}^{-2} \cdot \mathrm{s}^{-1}\right)$.

About $70 \%$ of all 'Bristol' and 'Jewel' explants extracted from seed of late-green or early yellow fruit were highly embryogenic regardless of 2,4-D concentration. Most embryoids originated directly from explant tissue and not through callus. Repetitive embryogenesis (Tulecke and McGranahan, 1985) was common in all of these cultures. Even though the initiation of embryogenesis occurred sooner on explants cultured on media containing 2,4$\mathrm{D}$, embryoids developed on such media exhibited many abnormalities, including polycotyledony, "rooty" masses, and increased anthocyanin production. Sixty-nine 'Jewel' and 14 'Bristol' normal embryoids (parallelling

Received for publication 24 Feb. 1992. Accepted for publication 12 Sept. 1992. Funded by the Ohio Thomas Edison Program, Ohio Dept. of Development. We thank Hugh Daubeny for supplying plant material and Luann Henry and Amy McMullen for technical assistance. The cost of publishing this paper was defrayed in part by the payment of page charges. Under postal regulations, this paper therefore must be hereby marked advertisement solely to indicate this fact.

${ }^{1}$ To whom reprint requests should be addressed. Present address: Dept. of Horticulture, The Ohio State Univ., Columbus, OH 43210. zygotic embryo development) were produced on growth regulator-free medium. When separated from embryogenic clumps and cultured individually on half-strength MS, $50 \%$ of the embryoids continued embryogenesis and only two (one 'Bristol', one 'Jewel') developed into plants (Fig. 1A). Twenty-five 'Jewel' and five 'Bristol' embryoids were subjected to chilling and desiccation treatments to stimulate germination, as previously described (Gingas and Lineberger, 1989), but without success. Plants were removed from culture and placed in a soilless 1 peat : 1 vermiculite $(\mathrm{v} / \mathrm{v})$ medium in $5-\mathrm{cm}^{3}$ pots covered by inverted beakers. Once acclimatized, they were transferred to $10-\mathrm{cm}^{3}$ peat pots and grown in the greenhouse until transplanted into the field (Fig. 1C).

Explants of 'Bristol', 'Jewel', and 'Exp72' excised at earlier stages of fruit ripening exhibited little or no development regardless of medium. Explants extracted from riper 'Bristol' and 'Jewel' fruit produced callus tissue that appeared to be transitional between embryogenesis and organogenesis. Clumps exhibited low-frequency embryogenesis as well as rooty masses and modified foliar structures on all media. 'Exp-72' explants extracted from yellow and early red fruit produced numerous adventitious shoots on medium containing 0 or $0.45 \mu \mathrm{M} 2,4-\mathrm{D}$. Such shoots proliferated when transferred to MS $+4.4 \mu \mathrm{M}$ benzyladenine (BA) and rooted when transferred to MS without growth regulators.

To increase explant material for further embryogenic studies, greenhouse-grown containerized plants of $R$. occidentalis 'Bristol' and 'Jewel' and $R$. idaeus '88-1', '88-2', and '883 ' were placed outdoors for 6 weeks during November and December to induce flowering and fruiting. After the plants were returned to the greenhouse, normal fruit set occurred and a second study was initiated. All explant material was extracted at the late-green or early yellow stages of fruit ripening and cultured on growth regulator-free medium. All other extraction and culture procedures were followed as described above. The number of cotyledon explants were 'Bristol', 61; 'Jewel', 692; '881', 20; '88-2', 20; '88-3', 27; and 'Jewel' $\mathrm{x}$ '88-2' (a hand-pollinated cross), 24.

Again, $\approx 70 \%$ of all explants were embryogenic. Embryogenic development was similar to that witnessed in the initial study for the same explantation periods and culture medium, regardless of cross or cultivar. Sixtyeight 'Jewel', nine 'Bristol', two '88-3', and

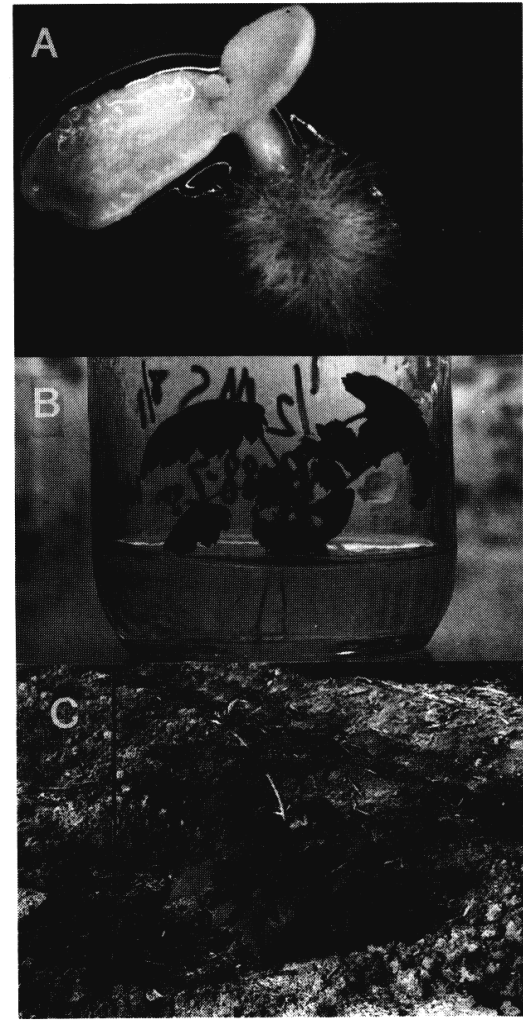

Fig. 1. Various developmental stages of Rubus plantlets derived from asexual embryogenesis: (A) normal 'Bristol' embryoid; (B) 'Jewel' $x$ '88-2' plantlet in culture; (C) 'Jewel' plantlet established in the field.

one 'Jewel' $\mathrm{x}$ ' 88 -2' normal embryoids were separated from clumps and cultured individually on half-strength MS. Of these, seven 'Jewel', one '88-3', and one 'Jewel' $x$ ' $88-2$ ' (Fig. 1B) developed into plants. Six of the eight 'Jewel' plants were derived from a single stock plant. Plants were acclimatized and transplanted as described above.

Even though 11 Rubus plants have been regenerated via asexual embryogenesis and are currently thriving under field conditions, this system must be greatly improved to increase efficiency. Results presented here indicate that regeneration appears to be influenced more by explant stage of development than by growth regulator additives as previously noted (Gingas and Lineberger, 1989). This conclusion holds for the embryogenic system applied to the cultivars described and the organogenic system witnessed on the 'Exp-72' explants.

\section{Literature Cited}

Fiola, J.A. and H.J. Swartz. 1986. Somatic embryogenesis, organogenesis and proliferation in vitro from Rubus embryos. Acta Hort. 183:91-98.

Gingas, V.M. and R.D. Lineberger. 1989. Asexual embryogenesis and plant regeneration in Quercus. Plant Cell Tissue Organ Cult. 17:191-203.

Murashige, T. and F. Skoog. 1962. A revised medium for rapid growth and bioassays with tobacco tissue cultures. Physiol. Plant. 15:479-497.

Tulecke, W. and G. McGranahan. 1985. Somatic embryogenesis and plant regeneration from cotyledons of walnut, Juglans regia L. Plant Sci. 40:57-63. 